\title{
Simvastatin and the Rho-kinase inhibitor Y-27632 prevent myofibroblast transformation in Peyronie's disease-derived fibroblasts via inhibition of YAP/TAZ nuclear translocation.
}

\author{
Milenkovic $U^{1,2}$, Ilg $M M^{3}$, Zuccato $C^{1,4}$, Ramazani $Y^{5}$, De Ridder $D^{1,2}$, Albersen $M^{1,2}$ \\ 1. Laboratory of Experimental Urology, Department of Development and Regeneration, KU Leuven, \\ Belgium \\ 2. Department of Urology, University Hospitals Leuven, Belgium \\ 3. Faculty of Health, Education, Medicine and Social Care, Medical Technology Research Centre, \\ Anglia Ruskin University, Chelmsford, UK \\ 4. Faculty of Medicine and Surgery, University of Padua, Italy \\ 5. Department of Pediatric Nephrology and Growth and Regeneration, University Hospitals Leuven \\ and KU Leuven, Belgium
}

\footnotetext{
${ }^{*}$ Corresponding author: Prof. Maarten Albersen, Department of Urology and Laboratory of Experimental Urology, Catholic University and University Hospitals Leuven, Herestraat 49, 3000 Leuven, Belgium; Email: maarten.albersen@uzleuven.be
}

Keywords: Fibrosis, Peyronie's disease, Transforming growth factor-beta, Rho-kinase inhibition, YAP/TAZ, Statins

\author{
Abstract word count: 328 \\ Text body word count: 3100 \\ Number of figures: 6 \\ Number of tables: 0
}




\section{Introduction}

Peyronie's disease (PD) is an acquired fibromatous disorder of the tunica albuginea (TA) causing progressive curvature of the penile shaft. In the initial (acute) phase it is characterised by erectile pain, devoid of a visible curvature. Within 12-24 months it evolves into a chronic, painless curvature (or other, e.g. hourglass deformity) of the penis (1). This deformity of the erect penis is caused by formation of localized contracted fibrotic plaques, which eventually may progress towards calcified or ossified scars (2). This phenomenon can impair sexual intercourse, cause erectile dysfunction (ED) and be the source of significant emotional distress and issues in the relationship (3).

Contemporary recommended treatment options include surgical correction of the deformity (4) or local injection of clostridium histolyticum collagenase, into the fibrotic plaques to break them down, correcting the deformities and thereby facilitating sexual intercourse (5). However, long-term results remain relatively unsatisfactory; primarily due to poor surgical outcomes with penile shortening and new onset erectile dysfunction (ED). Secondarily because currently available treatment options are merely symptomatic and do not target the underlying pathophysiological processes leading to PD (6). This lack of effective pharmacological treatments is the consequence of undiscovered molecular mechanisms that lead to the development of PD. The most widely accepted hypothesis dates back to 1997, which postulates that PD is caused by repetitive traumata to the erect penis during intercourse (7). The mechanical stress during intercourse causes the activation of latent transforming growth factor $\beta 1$ (TGF- $\beta 1$ ) from the extracellular matrix (ECM) and cells of the innate immunity $(8,9)$.

TGF- $\beta 1$ is a potent inducer of fibrosis by stimulating the production of pro-fibrotic molecules, such as connective tissue growth factor (CTGF or CCN2) (10). Additionally, TGF- $\beta 1$ incites the transformation of fibroblasts (FBs) into myofibroblasts with subsequent production of ECM (11). All fibrotic processes have the myofibroblast in common, characterised distinctly by expression of a-smooth muscle actin ( $\alpha-S M A)(12)$. This actin filament is incorporated into stress fibers, which results in increased cell contractility (12). These steps are the natural processes involved in the wound healing response that 
can lead to fibrosis, if exaggerated in case of untimely apoptosis (13). Hence, promising therapeutic strategies need to prevent a phenotypical switch to myofibroblast to prevent fibrosis in TA fibroblasts. This means an inhibition of expression of $\alpha$-SMA, CTGF, and ECM proteins needs to be established (14).

It has been shown that inhibition of Rho-associated coiled-coil forming protein kinase (ROCK) can attenuate TGF- $\beta 1$ signaling, resulting in impaired production of CTGF and ECM, as well as a decreased rate of fibroblast-to-myofibroblast transformation $(15,16)$. ROCK-signaling occurs partly through polymerization of G-actin to F-actin and subsequent nuclear translocation of yes-associated protein/transcriptional coactivator with PDZ-binding motif (YAP/TAZ) (17). The latter binds to the transcription factor transcriptional enhancer factor TEF-1 (TEAD) and M-CAT elements in the nucleus and drives the expression of several (pro-fibrotic) genes, including CTGF (18).

Statins are 3-hydroxy-3-methylglutaryl coenzyme-A (HMG-CoA) reductase inhibitors that are commonly being used for the primary and secondary prevention of cardiovascular morbidities because of their lipid-reducing and direct beneficial cardiovascular effects (19). In addition to their potency as inhibitors of cholesterol biosynthesis, statins possess immuno-modulatory and antiinflammatory properties (20). Statins exert their pleiotropic effects independently of their cholesterolinhibiting properties. Certain intermediates of the cholesterol biosynthesis (farnesyl pyrophosphate and geranylgeranyl pyrophosphate) are also essential for the post-translational modification of the Rho family of proteins $(20,21)$. Therefore, statins have the potential to become therapeutic agents for fibrotic diseases through their ROCK-inhibitory effects among others. The antifibrotic effects of statins have already been investigated in several organ systems, including intestinal, pulmonary, cardiac and renal parenchyma (22-25).

In PD, to the best of our knowledge, the antifibrotic effects of ROCK-inhibitors and statins have been tested neither in vitro nor in vivo. We hypothesized that ROCK-inhibitors and statins can serve as repurposed curative treatments for PD in the acute or chronic phase, reducing the need for surgical 
interventions. Here, we investigated the effects and mechanisms of ROCK-inhibitors and statins on myofibroblast formation, ECM production and the release of the matricellular protein, CTGF.

\title{
Materials and methods
}

\begin{abstract}
Patient samples
Tissue samples from TA were collected prospectively from patients receiving surgery for PD (partial plaque excision and grafting) $(\mathrm{N}=5)$. Samples were placed in cell culture medium until further processing. This study has been approved by the local ethics committee (Tracking number s59964).
\end{abstract}

\section{Fibroblast isolation from samples}

All samples were dissected with a scalpel ensuring no residual cavernosal tissue was present. Samples were cut into $3 \times 3 \mathrm{~mm}^{3}$ segments and placed onto a Petri dish (10 mm, Corning, US), cell culture medium was added (DMEM/F12, 10\% FBS supplemented with gentamicin and fungizone (Gibco, Thermo-Fisher, US)) and the fragments were left undisturbed for 5 days at $37^{\circ} \mathrm{C}, 5 \% \mathrm{CO}_{2}$ in a humidified atmosphere to ensure fibroblast attachment to the culture well. Once fibroblast growth was established (usually within 5-10 days), tissue fragments were removed, and medium changed every 2 to 3 days. At $80 \%$ confluence, cells were split using $0.25 \%$ trypsin with EDTA (Gibco, Thermo-Fisher, US) and reseeded in a T75 (Greiner Bio-One, Austria) flask for further expansion. Passage 2 to 6 were used for subsequent experiments.

\author{
Cell viability assay \\ Fibroblasts were plated into 96 well plates at 20,000 cells/well. Drugs (TGF- $\beta 1$, Y-27632, \\ simvastatin) were added the next day and cell viability was determined at 24 and $72 \mathrm{~h}$ after \\ treatment by Alamar Blue resazurin-based assay (Thermo-Fisher, US) according to manufacturer's \\ instructions.
}


Real-time quantitative-PCR (RT-qPCR)

Cells were seeded into 6 well plates (Corning, US) at $1.0 \times 10^{5}$ cells/well. After overnight incubation, the medium was replaced with either fresh medium, medium containing TGF- $\beta 1(3 \mathrm{ng} / \mathrm{mL})$, medium containing TGF- $\beta 1$ and Y-27632 (1-10-30 $\mu \mathrm{M}$; Stemcell Technologies, Canada) or medium containing TGF- $\beta 1$ and simvastatin (0.1-0.5-1.5-5-15 $\mu \mathrm{M}$, Sigma-Aldrich, UK) for $72 \mathrm{~h}$. Cell pellet was obtained by removing cells from the 6 well plates using trypsin and centrifugation at $1000 \mathrm{~g}$ for $5 \mathrm{~min}$. Total RNA was extracted from cells using the RNeasy Mini Kit (Qiagen, Germany), according to manufacturer's instructions. First strand cDNA was synthesized from 500 ng of RNA by reverse transcription (RT) using the High Capacity cDNA Reverse Transcription kit (Applied Biosystems, Thermo-Fisher, US), following the manufacturers protocol. Real-time PCR was performed utilizing the Taqman® PCR kit (Thermo-Fisher, US). TaqMan assay primers and probes mix (assays-on-demand TM Gene expression Products) were obtained from (Applied Biosystems, Thermo-Fisher, US). Reaction mixture $(25 \mu \mathrm{l})$ containing $1 \mu \mathrm{l}$ of cDNA template, $1 \mu \mathrm{l}$ of each primer and probe mix and TaqMan Universal PCR master mix (Applied Biosystems, Thermo-Fisher, US) amplified as follows: denaturation at $95^{\circ} \mathrm{C}$ for $10 \mathrm{~min}$ and 40 cycles at $95^{\circ} \mathrm{C}$ for $10 \mathrm{~s}, 60^{\circ} \mathrm{C}$ for $20 \mathrm{~s}$. Direct detection of PCR products monitored by measuring the fluorescence produced by the result of TaqMan probe hydrolysis after every cycle. Cycle times were analysed using the $\Delta \Delta \mathrm{Ct}$ method. Statistical analysis was performed using Graphpad Prism (v7.0) software.

\author{
Western Blot \\ Cells were seeded into 6 well plates (Corning, US) at $1.0 \times 10^{5}$ cells/well. After overnight incubation, \\ medium was replaced with either fresh medium, medium containing TGF- $\beta 1(3 \mathrm{ng} / \mathrm{mL})$, medium \\ containing TGF- $\beta 1$ and Y-27632 (1-10-30 $\mu \mathrm{M}$; Stemcell Technologies, Canada) or medium containing \\ TGF- $\beta 1$ and simvastatin (1.5-5 $\mu \mathrm{M}$, Sigma-Aldrich, UK) for $72 \mathrm{~h}$. Cell pellet was obtained by removing \\ cells from the 6 well plates using trypsin and centrifugation at $1000 \mathrm{~g}$ for $5 \mathrm{~min}$. \\ Protein concentration was determined by the BCA Protein Assay (Pierce, Thermo-Fisher, US). $30 \mu \mathrm{g}$ \\ of protein was loaded onto an SDS-PAGE gel (Bio-Rad Any kD Mini-Protean TGX, US) and transferred
}


to a PVDF membrane (Thermo-Fisher, US). After $1 \mathrm{~h}$ blocking in $10 \%$ non-fat dried milk, the membrane was incubated with primary antibodies (rabbit polyclonal anti-a-SMA (ab5694, 1:500, Abcam, UK) and mouse monoclonal anti-GAPDH (ab8245, 1:10000, Abcam, UK) at $4^{\circ} \mathrm{C}$ over-night, then washed with TBS $+0.1 \%$ Tween 20 (TBS-T), and probed with secondary antibodies (goat antirabbit/anti-mouse secondary antibody conjugated with HRP (ab205718/ab205719, 1:5000, Abcam, UK)), diluted in 5\% non-fat dried milk and TBS. Protein-antibody complexes were detected by G:BOX Chemi XRQ (Syngene, VWR, US). Quantitation of the signal was performed using ImageJ software. Statistical analysis was performed using Graphpad Prism (v7.0) software.

\section{Immunocytochemistry}

The cells were seeded into a 12 well plate (Corning, US) containing sterilized glass coverslips at 5.0 x $10^{4}$ cells/well. After over-night incubation, medium was replaced with either fresh medium, medium containing TGF- $\beta 1$ (3 ng/mL), medium containing TGF- $\beta 1$ and Y-27632 (30 $\mu \mathrm{M}$; Stemcell Technologies, Canada) or medium containing TGF- $\beta 1$ and simvastatin (1.5 $\mu \mathrm{M}$, Sigma-Aldrich, UK) for $72 \mathrm{~h}$.

Coverslips carrying the cells were washed in PBS and fixed using 4\% paraformaldehyde and 100\% ethanol. Coverslips were incubated with $10 \%$ natural goat serum (Dako, Belgium) in TBS for $1 \mathrm{~h}$ and further overnight with rabbit polyclonal anti- $\alpha-S M A$ antibody (ab5964, 1:200, Abcam, UK), mouse monoclonal anti-vimentin antibody (ab8789, 1:500, Abcam, UK) and mouse monoclonal anti-YAP/TAZ (sc-101199, 1:50, Santa Cruz, US). Slides were incubated for $1 \mathrm{~h}$ with goat anti-rabbit secondary antibody conjugated with fluorescein dye (ab150077, 1:250, Abcam, UK) and goat anti-mouse secondary antibody conjugated with fluorescein dye (ab150116, 1:250, Abcam, UK). Slides were then viewed and imaged using a Nikon Eclipse C1 microscope with NIS elements (Version 4.60) imaging software.

\section{Results}


TGF- $\beta 1$ induces a myofibroblast phenotype human fibroblasts and induces chemokine and ECM production

To show a homogenous PD-derived FB cell population devoid of smooth muscle cells (SMC) and/or myofibroblasts (MFB), RT-qPCR and immunofluorescence (IF) for vimentin (fibroblast marker), $\alpha-S M A$ (marker for MFB or SMC) and desmin (marker for SMC) were performed. Unstimulated cells had high expression of vimentin, while expression of $\alpha-S M A$ and desmin were comparatively nearly absent (Fig. 1A). Stainings for vimentin and a-SMA using IF revealed that unstimulated cells are positive for vimentin (Vim+) and negative for $\alpha-S M A(\alpha-S M A-)$ (Fig. 1B).

Upon TGF- $\beta 1$ stimulation, there was a significant increase in mRNA levels of $\alpha-S M A, C T G F$, collagen I, collagen III and elastin (Fig. 2A). Protein levels of $\alpha$-SMA were assessed using western blot (WB) and IF (Fig. 2B-C). Upon TGF- $\beta 1$ stimulation, the PD-derived FBs became $\mathrm{Vim}+$ and $\alpha-\mathrm{SMA}+$, suggesting their transformation into MFBs.

The Rho-kinase inhibitor Y-27632 inhibits myofibroblast transformation, CTGF and ECM production To investigate the effects of Rho-kinase inhibition on TGF- $\beta 1$-induced MFB transformation and production of ECM and CTGF, we co-incubated FBs with TGF- $\beta 13 \mathrm{ng} / \mathrm{mL}$ and increasing doses of the ROCK-inhibitor Y-27632. We assessed the effect of Y-27632 on cell viability and proliferation using a resazurin-based assay (Alamar Blue ${ }^{\mathrm{TM}}$ ). Figure 3A shows that $\mathrm{Y}-27632$ affected neither cell viability, nor the rate of proliferation. Figure $3 \mathrm{~B}$ shows there is no significant difference in caspase- 3 mRNA levels, further suggesting the lack of apoptosis-induction by Y-27632.

After $72 \mathrm{~h}$ of stimulation with TGF- $\beta 1$, $\alpha$-SMA was upregulated 6 -to-10-fold in stimulated cells compared to non-stimulated ones (Fig 2A). Incubation with Y-27632 reduced a-SMA mRNA expression by approximately half at the maximum concentration of $30 \mu \mathrm{M}$. We observed a similar pattern in mRNA levels of CTGF and collagen III (Fig. 4A). Seventy-two-hour incubation with TGF- $\beta 1$ resulted in a two-fold increase in a-SMA protein expression on WB, which was reversed to nonstimulated levels after treatment with Y-27632 (30 $\mu \mathrm{M})$ (Fig. 4B). Using IF, TGF- $\beta 1$ stimulated FBs were identified as MFB ( $\alpha-S M A+, V i m+)$ as opposed to the non-stimulated and Y-27632-treated cells 
(a-SMA-, Vim+) (Fig. 4C). Unstimulated FBs have low levels of nuclear expression and activity of YAP/TAZ. After $72 \mathrm{~h}$ of TGF- $\beta 1$ stimulation, a clear nuclear translocation of YAP/TAZ was detected on IF, which was prevented by treating these cells with Y-27632 (30 $\mu \mathrm{M})$ (Fig. 4D).

Simvastatin inhibits myofibroblast transformation, chemokine and ECM production.

To investigate the effects of simvastatin on TGF- $\beta 1$ induced MFB transformation and production of ECM and CTGF, FBs were incubated with TGF- $\beta 1$ and increasing doses of simvastatin.

First, the effect of simvastatin on cell viability and proliferation was assessed using a resazurin-based assay (Alamar Blue ${ }^{\mathrm{TM}}$ ). Figure 5A shows that simvastatin did not affect cell viability, but cells treated with simvastatin had a significantly slower growth rate. Figure 5B shows equal caspase-3 levels between all treatment groups.

When TGF- $\beta 1$ stimulated cells were treated with simvastatin the $\alpha$-SMA mRNA levels were decreased to pre-treatment levels. Similar observations could be made for mRNA expression of CTGF, elastin, collagen I and collagen III (Fig. 6A). A reversal to non-stimulated levels of $\alpha$-SMA protein expression after treatment with simvastatin was detected as well (Fig. 6B). Using IF, stimulated cells were identified as MFB ( $\alpha-S M A+, V i m+)$ as opposed to the non-stimulated and simvastatin-treated cells ( $\alpha$ SMA-, Vim+) (Fig. 6C).

After treatment with simvastatin the prevention of nuclear translocation of YAP/TAZ could be observed, suggesting that simvastatin might work through a similar pathway as ROCK-inhibition (Fig. 6D).

\section{Discussion}

Even though the use of ROCK-inhibitors and simvastatin has been described in other fibrotic diseases (22-25), these compounds remain uninvestigated in PD. This study explores the possible therapeutic potential of these compounds for the treatment of early or late-phase PD.

First, we characterized the cells isolated from PD-plaques. Unstimulated, harvested cells stained positive for vimentin and negative for $\alpha$-SMA, while desmin mRNA levels were nearly undetectable. 
Stimulation of the cells with TGF- $\beta 1$ caused a significant increase of $\alpha-S M A$ expression on mRNA and protein level, suggesting a myofibroblast phenotype (26). Furthermore, we also observed an increased level of ECM (collagen I, III and elastin) and CTGF mRNA production. This is the first report that suggests an upregulation of CTGF in TGF- $\beta 1$ stimulated PD-derived fibroblasts.

The role of myofibroblasts in fibrosis has been well established for over a decade (27). In physiological wound healing, they are responsible for wound contraction, production of ECM and several chemokines. Their delayed apoptosis can lead to persisting fibrogenesis and ultimately, fibrosis. The main signature of MFB is their co-expression of vimentin and $\alpha$-SMA, the latter being a marker that also occurs in smooth muscle cells (which are negative for vimentin) (28). Thus, inhibition of expression of $\alpha$-SMA can be used to study the rate of myofibroblast differentiation.

During inflammation and wound healing, myofibroblasts are formed from a diverse set of cell types. The initial trigger for myofibroblast formation can differ depending on its origin. For example, MFBs can develop from epithelial/endothelial-to-mesenchymal transition by TGF- $\beta 1$, IGF-1, EGF and FGF2 (29). Other sources are circulating bone marrow-derived fibrocytes which are activated by TGF- $\beta 1$ and endothelin-1 (30). Tissue resident fibroblasts undergo a transformation into myofibroblasts through TGF- $\beta 1$ (released from inflammatory macrophages and the extracellular matrix), IL-1b, PDGF and ROS (31). In PD, the origin of myofibroblasts is ill-investigated; nonetheless, it seems that TGF$\beta 1$ is the common denominator. Thus, inhibition of TGF- $\beta 1$-signaling would likely impair myofibroblast formation and subsequent fibrosis, regardless of the myofibroblast origin, especially since TGF- $\beta 1$ has been previously described as a main driver of myofibroblast transformation in PD $(8,32)$ to the extent that the most widely used animal model of the disease is based on injection of the cytokine $(9,33)$.

In this series of experiments, we found that $\mathrm{Y}-27632$ could significantly impede TGF- $\beta 1$ induced myofibroblast transformation, as evidenced on an mRNA and protein level, while there was also a significantly reduced expression of CTGF and collagen III. This data suggest that ROCK-inhibitors can inhibit the formation of myofibroblasts, and hence inhibit their secretory capabilities. Interestingly, 
ROCK-inhibitors have also been shown to improve smooth muscle cell relaxation in human corpus cavernosum (34). Considering that most patients with PD also have erectile dysfunction (ED) (4), therapy with ROCK-inhibitors could not only lead to attenuated fibrosis, but also improvement of erectile function. In the canonical pathway, TGF- $\beta 1$ signalling occurs via phosphorylation and nuclear translocation of SMAD-proteins $(35,36)$. Additionally, TGF- $\beta 1$ has been shown to induce myofibroblast transformation by acting on the ROCK signalling axis. Mechanistically, in this study, we suggest that TGF- $\beta 1$ signalling in TA-derived fibroblasts occurs through ROCK-mediated YAP/TAZ nuclear translocation. This nuclear activity of YAP/TAZ leads to transcription of several pro-fibrotic genes, including collagens and CTGF (18), and further investigation of this pathway may lead to novel treatment targets.

Statins have been used for decades in the treatment of atherosclerosis and secondary prevention of cardiovascular disease (19). However, a role for them in PD-related fibrosis has never been reported. Our findings could suggest that active plasma levels of simvastatin could be beneficial for inhibition of fibroblast to myofibroblast transformation and thus impeded fibrogenesis in a clinical setting. We show in our experiments that simvastatin is a very potent inhibitor of myofibroblast transformation, production of ECM (collagen I, III and elastin) and CTGF mRNA. Additionally, the proliferation of PDderived FBs was attenuated compared to controls or TGF- $\beta 1$ stimulated cells. As has been described earlier, simvastatin exerts its effect partly through inhibition of the ROCK-pathway, as evidenced by the inhibition of the nuclear translocation of YAP/TAZ $(24,36,37)$.

Although more mechanistic studies need to be performed to demonstrate the exact mechanisms of action of ROCK-inhibitors and simvastatin, our study demonstrates for the first time, that they could be beneficial in curbing early fibrogenesis and plaque development in PD patients. We also showed for the first time that TGF- $\beta 1$ stimulation of TA-derived fibroblasts leads to a significant upregulation of CTGF mRNA expression. Additionally, this increase could be attenuated (Y-27632) or prevented completely (simvastatin). Upregulation of CTGF has already been described in fibrotic diseases of 
lung, liver and kidney amongst others (38). CTGF, as a matricellular protein, exerts its fibrotic effects through several mechanisms: binding to cell surface receptors and initiating signal transductions, binding to cytokines and mediating their binding to specific receptors, remodelling the extracellular matrix turnover and regulating the activity of cytokines and growth factors through signalling cross talks (39). Our data suggests that YAP/TAZ nuclear translocation, at least partially, drives CTGF activation. YAP/TAZ has been shown to be an effective CTGF stimulator in kidney and corneal epithelial cells and endothelial cells to mention a few (40-42).

Inhibiting CTGF with direct pharmacological interventions might offer additional treatment options for PD. The CTGF monoclonal antibody FG-3019/pamrevlumab, for instance, has been demonstrated to be well-tolerated and effective in a phase II clinical trial of idiopathic pulmonary fibrosis and is currently being tested for muscular dystrophy and pancreatic cancer in clinical trials (43).

Further experiments assessing the precise downstream effectors (other than ROCK-signaling) need to be performed to elucidate the mechanism of action of simvastatin in PD-derived FBs. Additionally, to translate this into a clinical setting, in vivo studies using statins in a PD animal model need to be carried out. Nonetheless, Y-27632 and simvastatin show considerable potential in the search for much-needed, novel therapeutics in PD.

\section{Conclusion}

Using patient tunica albuginea fibroblasts derived from patients suffering from Peyronie's disease, we set up an in vitro model of PD using TGF- $\beta 1$ stimulation. We were able to show the anti-myofibroblast and anti-ECM producing properties of $\mathrm{Y}-27632$ and simvastatin in this in vitro setting. Both ROCKinhibition and HMG-coA reductase inhibitors could provide fascinating new outlooks on the medical treatment of Peyronie's disease in the near future.

\section{Acknowledgements}

The authors have no conflicts of interest to report. 
This research has been funded by the Fund for Peyronie's Disease Research, European Society for Sexual Medicine and the Fund for Translational Biomedical Research (FTBR) ("Klinische Onderzoeksen Opleidingsraad" (KOOR)) of KU/UZ Leuven.

\section{References}

1. Anaissie J, Yafi FA, Delay KJ, Traore EJ, Sikka SC, Hellstrom WJG. Peyronie' s Disease. Urology. 2016;100:125-30.

2. Levine L, Rybak J, Corder C, Farrel MR. Peyronie's Disease Plaque Calcification-Prevalence, Time to Identification, and Development of a New Grading Classification. J Sex Med. 2013 Dec $1 ; 10(12): 3121-8$.

3. Liu Q, Zhang Y, Wang J, et al. Erectile Dysfunction and Depression: A Systematic Review and Meta-Analysis. J Sex Med. 2018 Aug 1;15(8):1073-82.

4. Carson CC, Levine LA. Outcomes of surgical treatment of Peyronie' s disease. BJU Int. 2014;70413.

5. Russo GI, Milenkovic U, Hellstrom W, Levine LA, Ralph D, Albersen M. Clinical Efficacy of Injection and Mechanical Therapy for Peyronie's Disease: A Systematic Review of the Literature. Eur Urol. 2018 Sep 17.

6. Hatzichristodoulou G, Osmonov D, Kübler H, Hellstrom WJG, Yafi FA. Contemporary Review of Grafting Techniques for the Surgical Treatment of Peyronie's Disease. Sex Med Rev. 2017;1-9.

7. Devine CJJ, Somers KD, Jordan GH, Schlossberg SM. Proposal: Trauma as the Cause of the Peyronie's Lesion. J Urol. 1997 Jan 1;157(1):285-90.

8. Gonzalez-Cadavid NF, Rajfer J. Mechanisms of Disease: new insights into the cellular and molecular pathology of Peyronie's disease. Nat Clin Pract Urol. 2005 Jun 1;2(6):291-7.

9. El-sakka Al, Hassoba HM, Chui RM, Bhatnagar RS, Dahiya R, Lue TOMF. An animal model of peyronie' s-like condition associated with an increase of transforming growth factor beta mRNA and protein expression. J Urol 1997;158:2284-90.

10. Xie S, Sukkar MB, Issa R, Oltmanns U, Nicholson AG, Chung KF. Regulation of TGF- $\beta 1$-induced 
connective tissue growth factor expression in airway smooth muscle cells. Am J Physiol Cell Mol Physiol. 2005 Jan;288(1):L68-76.

11. Hinz B. The extracellular matrix and transforming growth factor- $\beta 1$ : Tale of a strained relationship. Matrix Biol. 2015 Sep 1;47:54-65.

12. Tomasek JJ, Gabbiani G, Hinz B, Chaponnier C, Brown R. Myofibroblasts and mechanoregulation of connective tissue remodelling. Nat Rev Mol Cell Biol. 2002;3(5):349-63.

13. Desmoulière A, Redard M, Darby I, Gabbiani G. Apoptosis mediates the decrease in cellularity during the transition between granulation tissue and scar. Am J Pathol. 1995 Jan;146(1):56-66.

14. Mun J-H, Kim Y-M, Kim B-S, Kim J-H, Kim M-B, Ko H-C. Simvastatin inhibits transforming growth factor- $\beta 1$-induced expression of type I collagen, CTGF, and $\alpha$-SMA in keloid fibroblasts. Wound Repair Regen. 2014 Jan;22(1):125-33.

15. Bhowmick NA, Ghiassi M, Bakin A, et al. Transforming Growth Factor- $\beta 1$ Mediates Epithelial to Mesenchymal Transdifferentiation through a RhoA-dependent Mechanism. Mol Biol Cell. 2001 Jan;12(1):27-36.

16. Yamamoto M, Quantock AJ, Young RD, et al. A selective inhibitor of the Rho kinase pathway, Y27632, and its influence on wound healing in the corneal stroma. Mol Vis. 2012;18:1727-39.

17. Knipe RS, Tager AM, Liao JK. The Rho Kinases : Critical Mediators of Multiple Profibrotic Processes and Rational Targets for New Therapies for Pulmonary Fibrosis. Pharmacol Rev. 2015;085006(January):103-17.

18. Zhao B, Ye X, Yu J, et al. TEAD mediates YAP-dependent gene induction and growth control. Genes Dev. 2008 Jul 15;22(14):1962-71.

19. Zhou Q, Liao JK. Statins and cardiovascular diseases: from cholesterol lowering to pleiotropy. Curr Pharm Des. 2009;15(5):467-78.

20. Greenwood J, Steinman L, Zamvil SS. Statin therapy and autoimmune disease: from protein prenylation to immunomodulation. Nat Rev Immunol. 2006 May 1;6(5):358-70.

21. Bolognin S, Lorenzetto E, Diana G, Buffelli M. The Potential Role of Rho GTPases in Alzheimer's Disease Pathogenesis. Mol Neurobiol. 2014;50(2):406-22.

22. Abe $\mathrm{Y}$, Murano M, Murano N, et al. Simvastatin Attenuates Intestinal Fibrosis Independent of the 
Anti-Inflammatory Effect by Promoting Fibroblast/Myofibroblast Apoptosis in the Regeneration/Healing Process from TNBS-Induced Colitis. Dig Dis Sci. 2012 Feb 11;57(2):33544.

23. Yamamoto C, Fukuda N, Jumabay M, et al. Protective effects of statin on cardiac fibrosis and apoptosis in adrenomedullin-knockout mice treated with angiotensin II and high salt loading. Hypertens Res. 2011 Mar 16;34(3):348-53.

24. Watts KL, Sampson EM, Schultz GS, Spiteri MA. Simvastatin Inhibits Growth Factor Expression and Modulates Profibrogenic Markers in Lung Fibroblasts. Am J Respir Cell Mol Biol. 2005 Apr 20;32(4):290-300.

25. Goppelt-Struebe M, Hahn A, Iwanciw D, Rehm M, Banas B. Regulation of connective tissue growth factor (ccn2; ctgf) gene expression in human mesangial cells: modulation by HMG CoA reductase inhibitors (statins). Mol Pathol. 2001 Jun 1;54(3):176-9.

26. Duffield JS. Cellular and molecular mechanisms in kidney fibrosis. J Clin Invest. 2014 Jun 2;124(6):2299-306.

27. Bochaton-Piallat M-L, Gabbiani G, Hinz B. The myofibroblast in wound healing and fibrosis: answered and unanswered questions. F1000Research. 2016;5.

28. Rensen SSM, Doevendans PAFM, van Eys GJJM. Regulation and characteristics of vascular smooth muscle cell phenotypic diversity. Neth Heart J. 2007;15(3):100-8.

29. Lamouille S, Xu J, Derynck R. Molecular mechanisms of epithelial-mesenchymal transition. Nat Rev Mol Cell Biol. 2014 Mar 1;15(3):178-96.

30. McAnulty RJ. Fibroblasts and myofibroblasts: Their source, function and role in disease. Int J Biochem Cell Biol. 2007;39(4):666-71.

31. Hinz B, Phan SH, Thannickal VJ, et al. Recent Developments in Myofibroblast Biology. Am J Pathol. 2012 Apr;180(4):1340-55.

32. Gelfand RA, Vernet D, Kovanecz I, Rajfer J, Gonzalez-Cadavid NF. The transcriptional signatures of cells from the human Peyronie's disease plaque and the ability of these cells to generate a plaque in a rat model suggest potential therapeutic targets. J Sex Med. 2015 Feb;12(2):313-27.

33. Bivalacqua TJ, Diner EK, Novak TE, et al. A rat model of peyronie's disease associated with a 
34. Uvin P, Albersen M, Bollen I, et al. Additive effects of the Rho kinase inhibitor Y-27632 and vardenafil on relaxation of the corpus cavernosum tissue of patients with erectile dysfunction and clinical phosphodiesterase type 5 inhibitor failure. BJU Int. 2017 Feb;119(2):325-32.

35. Massagué J. How cells read TGF-beta signals. Nat Rev Mol Cell Biol. 2000;1(3):169-78.

36. Piersma B, Bank RA, Boersema M. Signaling in fibrosis : TGF- $\beta$, WNT, and YAP / TAZ converge. 2015;2(September):1-14.

37. Cordle A, Koenigsknecht-talboo J, Wilkinson B, Limpert A, Landreth G. Mechanisms of Statinmediated Inhibition of Small G-protein Function. J Biol Chem. 2005;280(40):34202-9.

38. Cannito S, Novo E, Parola M. Therapeutic pro-fibrogenic signaling pathways in fibroblasts. Adv Drug Deliv Rev. 2017;121:57-84.

39. Ramazani Y, Knops N, Elmonem MA, et al. Connective tissue growth factor (CTGF) from basics to clinics. Matrix Biol. 2018 Aug;68-69:44-66.

40. Raghunathan VK, Dreier B, Morgan JT, et al. Involvement of YAP, TAZ and HSP90 in contact guidance and intercellular junction formation in corneal epithelial cells. PLoS One. 2014 Oct 7;9(10):e109811.

41. Preisser F, Giehl K, Rehm M, Goppelt-Struebe M. Inhibitors of oxygen sensing prolyl hydroxylases regulate nuclear localization of the transcription factors Smad2 and YAP/TAZ involved in CTGF synthesis. Biochim Biophys Acta. 2016 Aug;1863(8):2027-36.

42. Nagasawa-Masuda A, Terai K. Yap/Taz transcriptional activity is essential for vascular regression via Ctgf expression and actin polymerization. PLoS One. 2017 Apr 3;12(4):e0174633.

43. Raghu G, Scholand MB, de Andrade J, et al. FG-3019 anti-connective tissue growth factor monoclonal antibody: results of an open-label clinical trial in idiopathic pulmonary fibrosis. Eur Respir J. 2016 May;47(5):1481-91. 


\section{Figure legends}

Figure 1.

(A) RT-qPCR shows the ratio of vimentin (VIM), desmin (DES) and a-smooth muscle actin (ACTA2) mRNA expression; high expression of VIM in contrast to nearly undetectable DES and ACTA2 suggests a fibroblast phenotype $(\mathrm{N}=4)$. Error bars represent standard error of the mean. Pvalue was considered significant if $<0.05$.

(B) Using immunofluorescence, unstimulated cells were identified as being fibroblasts (VIM+), DAPI was used as a nuclear stain. Unstimulated cells showed nearly absent $\alpha$-smooth muscle actin staining.

Figure 2.

(A) RT-qPCR shows the upregulated genes after TGF- $\beta 1$ stimulation with $3 \mathrm{ng} / \mathrm{mL}$ after 72 h. $\alpha-$ smooth muscle actin (ACTA2) is the most important marker for fibroblast to myofibroblast 
transformation. Upregulation of the matricellular protein connective tissue growth factor (CTGF) can suggest a regulatory role of this protein in extracellular matrix turnover (collagen I-III and elastin) (N=4). Error bars represent standard error of the mean. P-value was considered significant if $<0.05$.

(B) Western blot confirms the upregulation of $\alpha$-smooth muscle actin ( $\alpha$-SMA) on a protein level in response to TGF- $\beta 1$ stimulation $(\mathrm{N}=3)$. Data is expressed as relative expression compared to the endogenous control (GAPDH) and to the unstimulated condition (T0) (30 $\mu \mathrm{g}$ of protein was loaded). Error bars represent standard error of the mean. P-value was considered significant if $<0.05$.

(C) Using immunofluorescence, cells stimulated with TGF- $\beta 1(3 \mathrm{ng} / \mathrm{mL})$ for $72 \mathrm{~h}$ were identified as being myofibroblasts (Vimentin (Vim)+ and $\alpha-S M A+$, DAPI was used as a nuclear stain).

Figure 3.

(A) Using Alamar Blue ${ }^{\mathrm{TM}}$, cells stimulated with TGF- $\beta 1$ (T) $(3 \mathrm{ng} / \mathrm{mL})$ and $\mathrm{Y}-27632(\mathrm{R})(1-10-30$ $\mu \mathrm{M})$ after $72 \mathrm{~h}$ showed no difference in cell proliferation and viability $(\mathrm{N}=4)$. Error bars represent standard error of the mean. P-value was considered significant if $<0.05$.

(B) RT-qPCR shows non-significant levels of caspase-3 mRNA expression between unstimulated, stimulated and Y-27632 treatment. Error bars represent standard error of the mean. P-value was considered significant if $<0.05$.

T0 = TGF- $\beta 10 \mathrm{ng} / \mathrm{mL} ; \mathrm{T} 3=\mathrm{TGF}-\beta 13 \mathrm{ng} / \mathrm{mL} ; \mathrm{T} 3+\mathrm{R} 1=\mathrm{TGF}-\beta 13 \mathrm{ng} / \mathrm{mL}+\mathrm{Y}-276321 \mu \mathrm{M} ; \mathrm{T} 3+\mathrm{R} 10=$



Figure 4.

(A) RT-qPCR graphs are normalized to the TGF- $\beta 1$ stimulated situation. After $72 \mathrm{~h}$, an upregulation of ( $\alpha$-smooth muscle actin) ACTA2, collagen III and connective tissue growth factor (CTGF) compared to non-stimulated cells could be observed (fig.2B). When treated with Y-27632, the ACTA2, collagen III and CTGF mRNA expression was partially impeded. Error bars represent standard error of the mean. P-value was considered significant if $<0.05$. 
(B) There is a two-fold increased protein expression of $\alpha$-smooth muscle actin ( $\alpha$-SMA) after TGF$\beta 1$ stimulation. When cells where treated with increasing doses of $Y-27632$, the protein expression returned to normal levels on WB. Data is expressed as relative expression compared to the endogenous control (GAPDH) and to the unstimulated condition (T0) (30 $\mu \mathrm{g}$ of protein was loaded). Error bars represent standard error of the mean. P-value was considered significant if $<0.05$.

(C) Using immunofluorescence, when TGF- $\beta 1$ stimulated cells were treated with Y-27632, expression of $\alpha-S M A$ returns to unstimulated levels (nuclear stain DAPI).

(D) Immunofluorescence stainings revealed low nuclear translocation of YAP/TAZ in unstimulated cells (left). When cells were exposed to TGF- $\beta 13 \mathrm{ng} / \mathrm{mL}$ (middle), YAP/TAZ was translocated into the nucleus. Treatment of stimulated cells with $\mathrm{Y}-2763230 \mu \mathrm{M}$ (right) returned nuclear staining of YAP/TAZ to pre-stimulation levels (nuclear stain DAPI).

T0 = TGF $-\beta 10 \mathrm{ng} / \mathrm{mL} ; \mathrm{T} 3$ = TGF- $\beta 13 \mathrm{ng} / \mathrm{mL} ; \mathrm{T} 3+\mathrm{R} 1=\mathrm{TGF}-\beta 13 \mathrm{ng} / \mathrm{mL}+\mathrm{Y}-276321 \mu \mathrm{M} ; \mathrm{T} 3+\mathrm{R} 10=$ TGF- $\beta 13 \mathrm{ng} / \mathrm{mL}+\mathrm{Y}-2763210 \mu \mathrm{M} ; \mathrm{T} 3+\mathrm{R} 30=\mathrm{TGF}-\beta 13 \mathrm{ng} / \mathrm{mL}+\mathrm{Y}-2763230 \mu \mathrm{M}$

Figure 5.

(A) Using Alamar Blue ${ }^{\mathrm{TM}}$, cells stimulated with TGF- $\beta 1(3 \mathrm{ng} / \mathrm{mL})$ and simvastatin $(0.5-1.5-5 \mu \mathrm{M})$ after $72 \mathrm{~h}$ showed a significantly impediment in cell proliferation, while viability was maintained. Error bars represent standard error of the mean. P-value was considered significant if $<0.05$.

(B) RT-qPCR shows non-significant levels of caspase-3 mRNA expression between unstimulated, stimulated and simvastatin treatment. Error bars represent standard error of the mean. P-value was considered significant if $<0.05$.

T0 = TGF- $\beta 10 \mathrm{ng} / \mathrm{mL} ;$ T3 = TGF- $\beta 13 \mathrm{ng} / \mathrm{mL} ; \mathrm{T} 3+\mathrm{S} 0.5$ = TGF- $\beta 13 \mathrm{ng} / \mathrm{mL}+$ Simvastatin $0.5 \mu \mathrm{M}$; T3+S1.5 = TGF- $\beta 13 \mathrm{ng} / \mathrm{mL}+$ Simvastatin $1.5 \mu \mathrm{M} ; \mathrm{T} 3+\mathrm{S} 5$ = TGF- $\beta 13 \mathrm{ng} / \mathrm{mL}+$ Simvastatin $5 \mu \mathrm{M}$; T3+S15 = TGF- $\beta 13 \mathrm{ng} / \mathrm{mL}+$ Simvastatin $15 \mu \mathrm{M} ; \mathrm{T} 3+\mathrm{V}=\mathrm{TGF}-\beta 13 \mathrm{ng} / \mathrm{mL}+$ Vehicle 
Figure 6.

(A) RT-qPCR graphs are normalized to the TGF- $\beta 1$ stimulated situation. After $72 \mathrm{~h}$, an upregulation of ( $\alpha$-smooth muscle actin) ACTA2, collagen III and connective tissue growth factor (CTGF) compared to non-stimulated cells could be observed (fig.2B). When treated with simvastatin, the ACTA2, collagen III and CTGF mRNA expression was suppressed significantly. Error bars represent standard error of the mean. P-value was considered significant if $<0.05$.

(B) There is a two-fold increase in protein expression of $\alpha$-smooth muscle actin ( $\alpha-S M A)$ upon TGF- $\beta 1$ stimulation. When cells were treated with simvastatin, the protein expression returned to normal levels on WB. Data is expressed as relative expression compared to the endogenous control (GAPDH) and to the unstimulated condition (T0) (30 $\mathrm{\mu g}$ of protein was loaded). Error bars represent standard error of the mean. P-value was considered significant if $<0.05$.

(C) Immunofluorescence staining of TGF- $\beta 1$ stimulated cells treated with simvastatin. Staining for a-SMA returned to unstimulated levels (nuclear stain DAPI).

(D) Immunofluorescence staining revealed low nuclear translocation of YAP/TAZ (left) in unstimulated cells (left). When cells were exposed to TGF- $\beta 1$ ( $3 \mathrm{ng} / \mathrm{mL}$ ) (middle), YAP/TAZ was translocated to the nucleus. When treating these stimulated cells with simvastatin $1.5 \mu \mathrm{M}$ (right), nuclear staining of YAP/TAZ returned to pre-stimulation levels (nuclear stain DAPI).

T0 = TGF- $\beta 10 \mathrm{ng} / \mathrm{mL} ;$ T3 = TGF- $\beta 13 \mathrm{ng} / \mathrm{mL} ; \mathrm{T} 3+\mathrm{S} 0.5$ = TGF- $\beta 13 \mathrm{ng} / \mathrm{mL}+$ Simvastatin $0.5 \mu \mathrm{M}$; T3+S1.5 = TGF- $\beta 13 \mathrm{ng} / \mathrm{mL}+$ Simvastatin $1.5 \mu \mathrm{M} ; \mathrm{T} 3+\mathrm{S} 5=\mathrm{TGF}-\beta 13 \mathrm{ng} / \mathrm{mL}+$ Simvastatin $5 \mu \mathrm{M}$; T3+S15 = TGF- $\beta 13 \mathrm{ng} / \mathrm{mL}+$ Simvastatin $15 \mu \mathrm{M} ; \mathrm{T} 3+\mathrm{V}=\mathrm{TGF}-\beta 13 \mathrm{ng} / \mathrm{mL}+$ Vehicle 
Figure $1 \mathrm{~A}$.

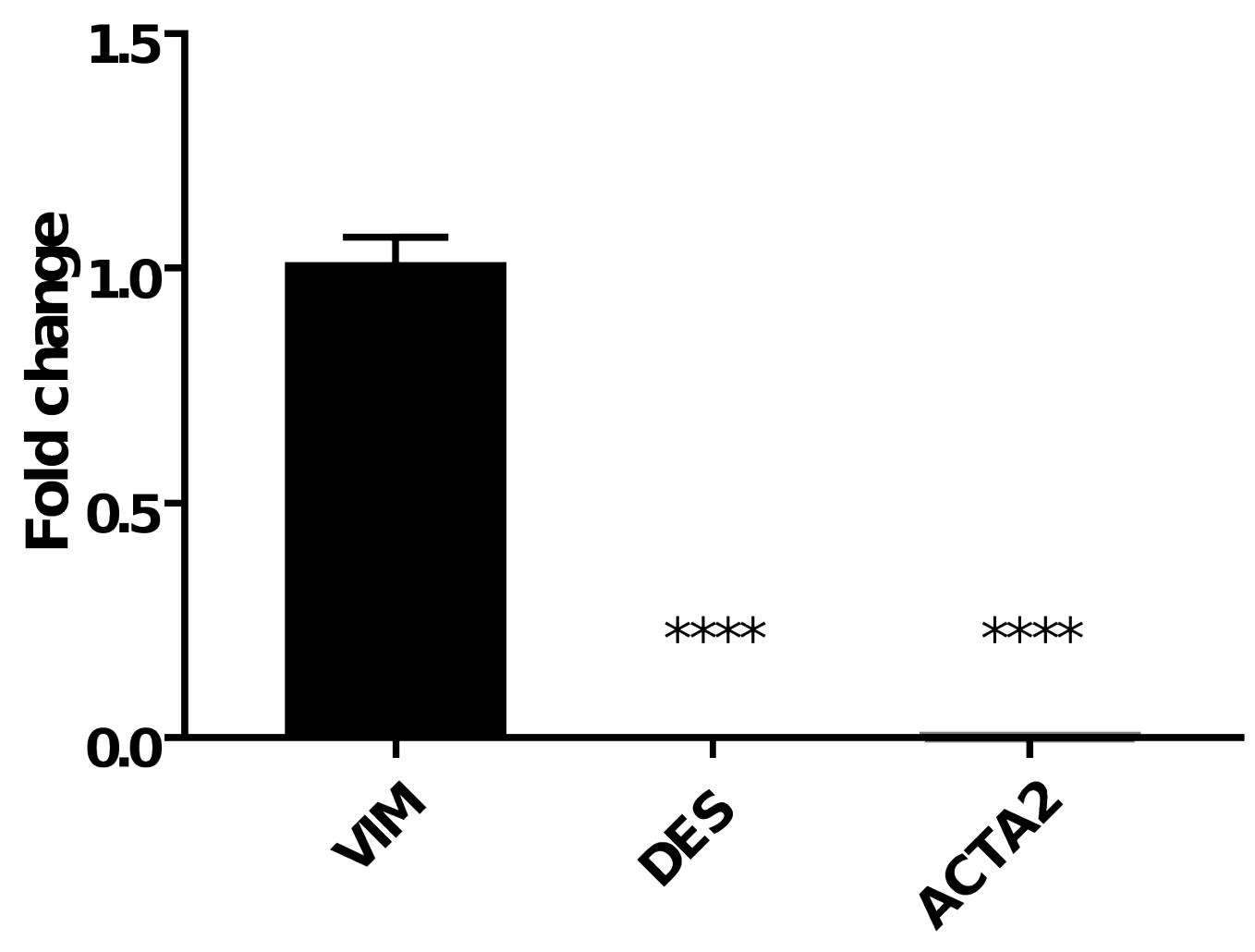


Figure 1B.

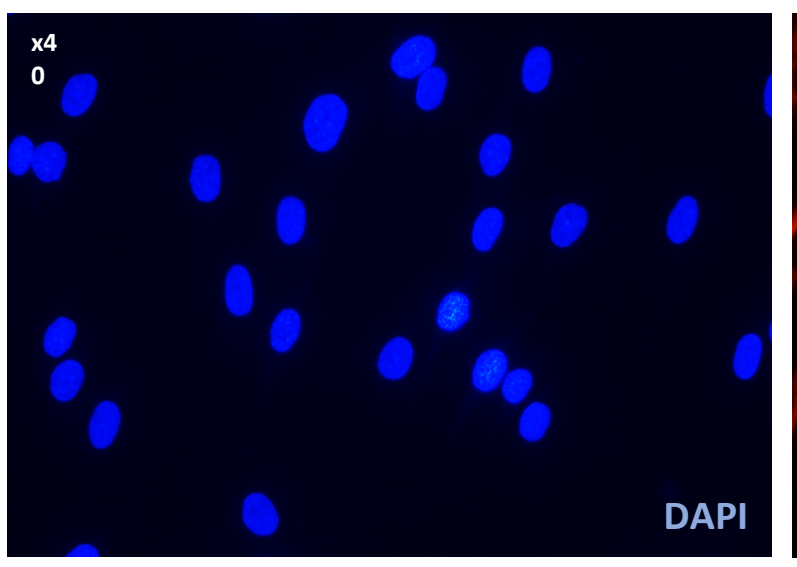

$x 40$

$\times 20$

x20



VIM

$\alpha-S M A$



x20

DAPI

$\alpha$-SMA 
Figure 2A-B.

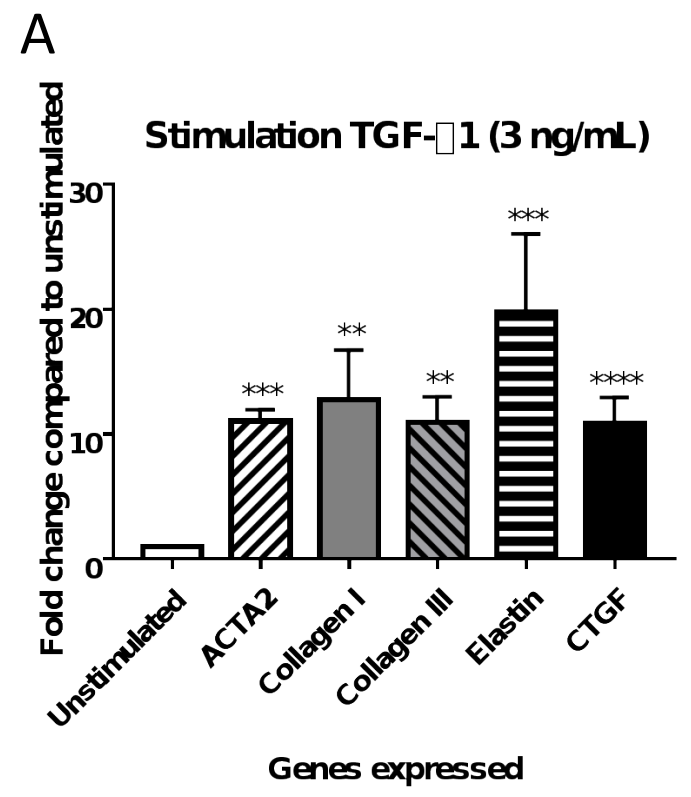

B $\alpha-S M A(42$ kDa)
GAPDH (37 kDa) TO T3 
Figure 2C.


x20
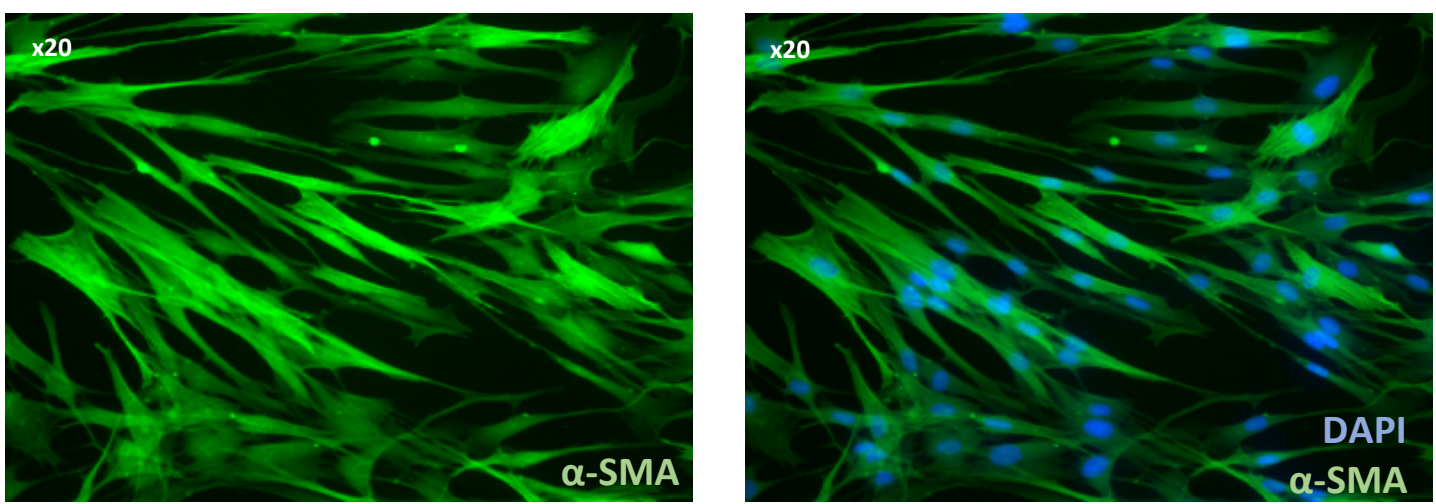
Figure 3A-B.
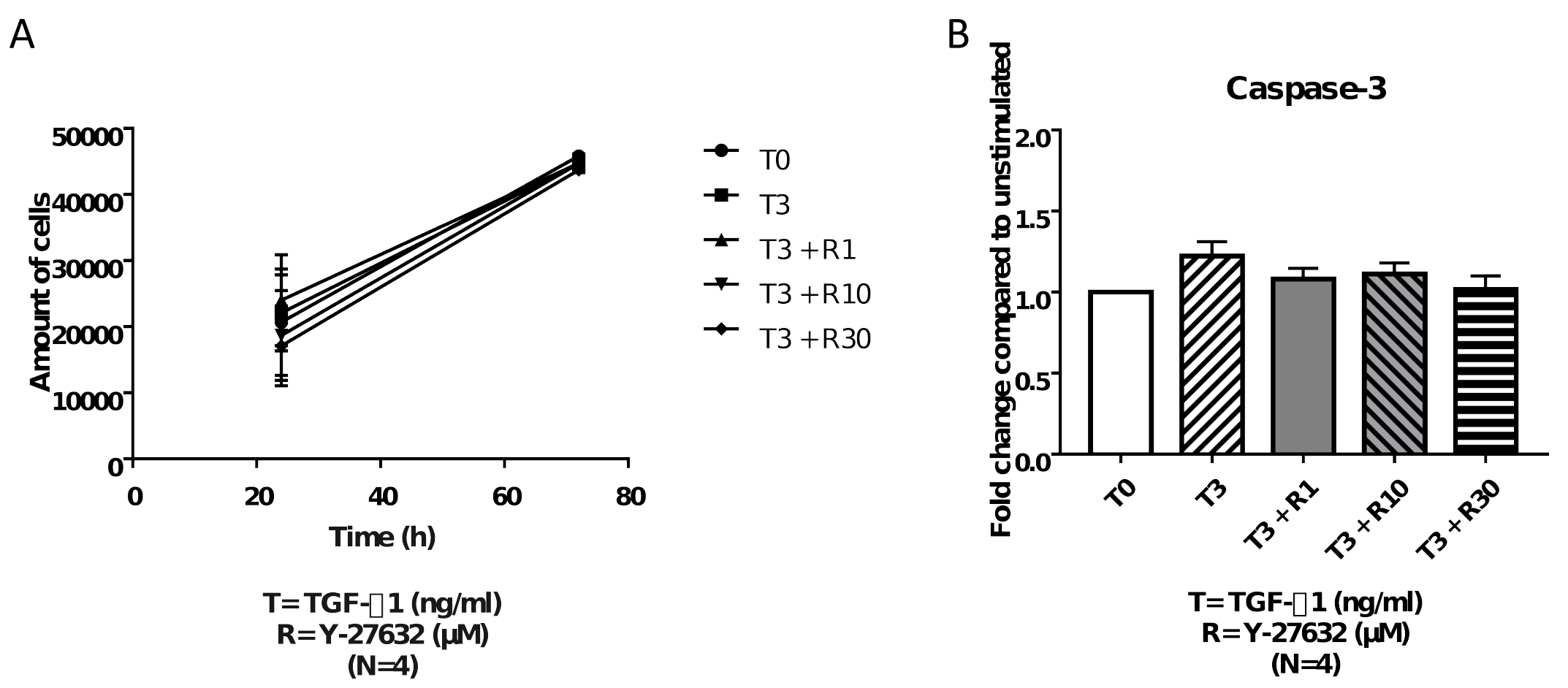


$$
\text { An }
$$


Figure 4B.

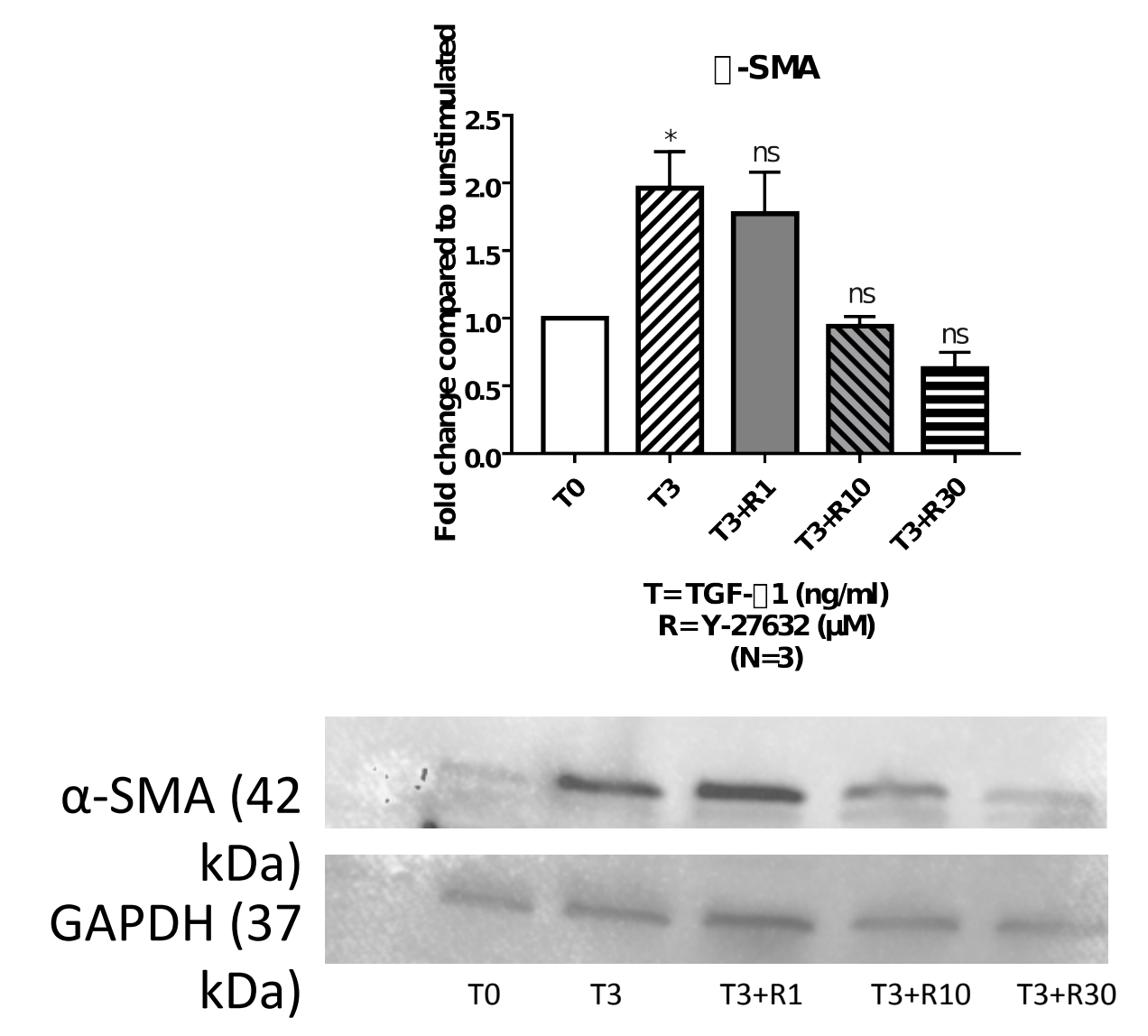


Figure 4C.




Figure 4D.

Unstimulated

TGF- $\beta 1$

TGF- $\beta 1+Y-27632$

8
9
10
1
1
1
1
15
16
1
18
15
20
2
2
2
2
2
26
2
28
25
3(
3
32
3
3
35
36
3
38
35
4
4

$x 20$

$\times 20$

x

DAF

DAP

x20

9
12
13
14
16
18
19
21

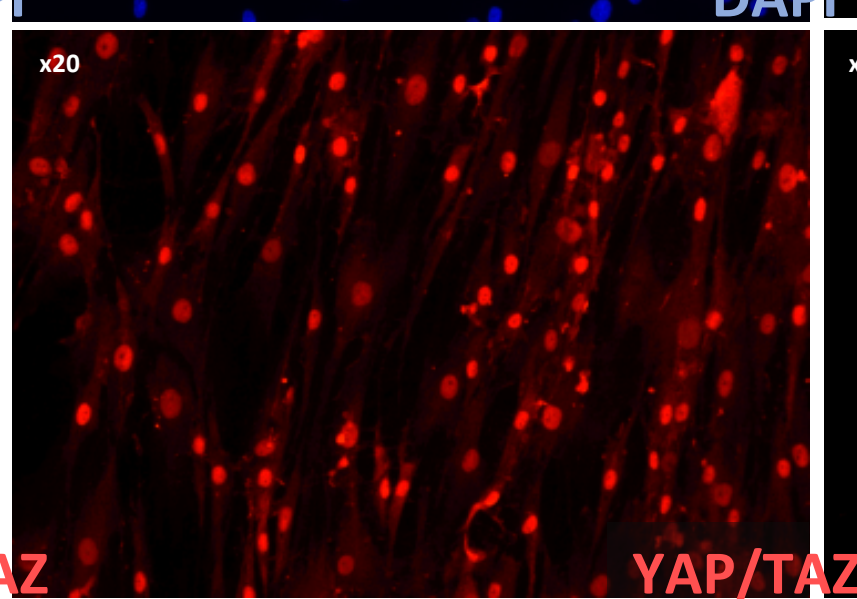

DAP 
Figure 5A-B.

A

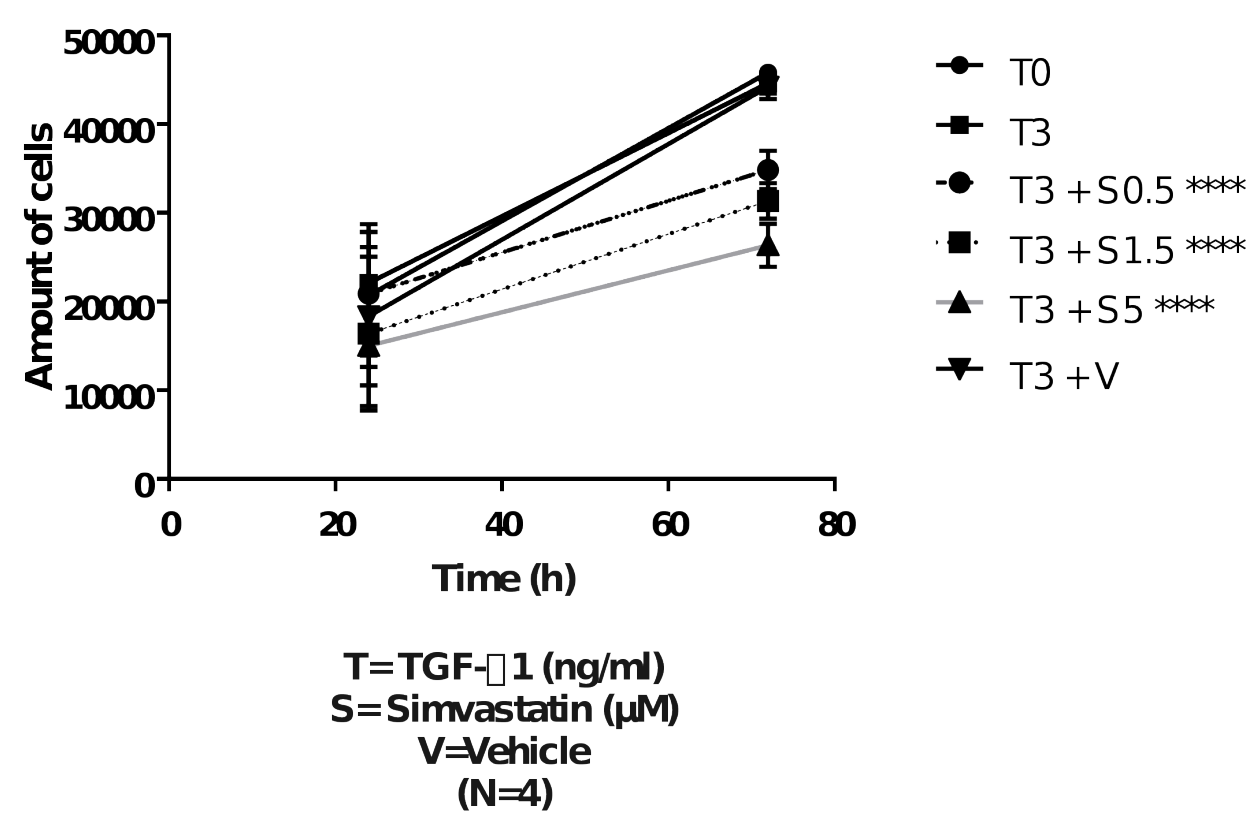

B

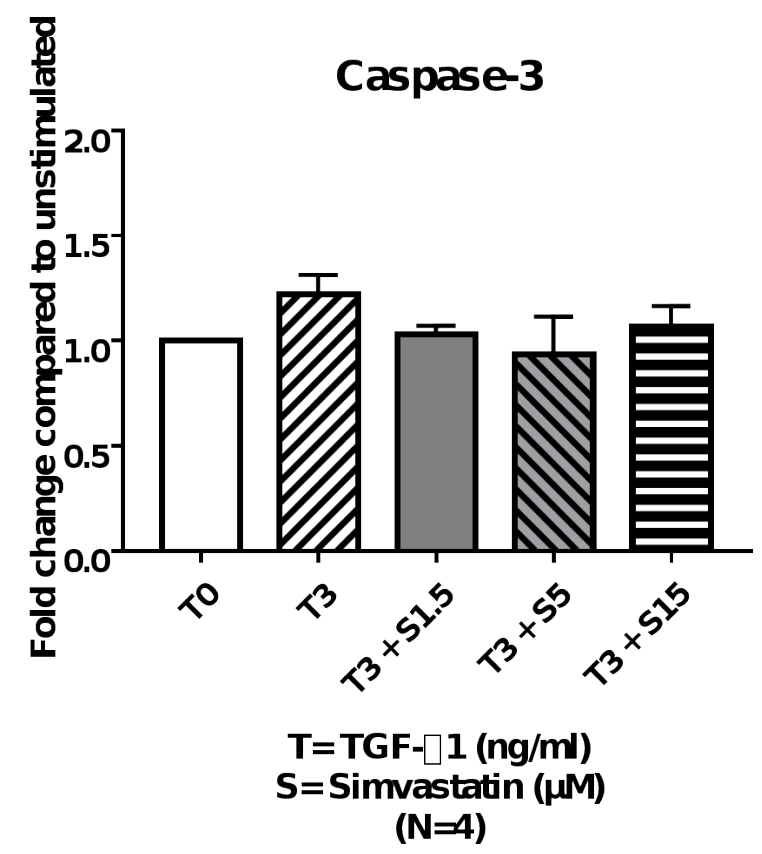




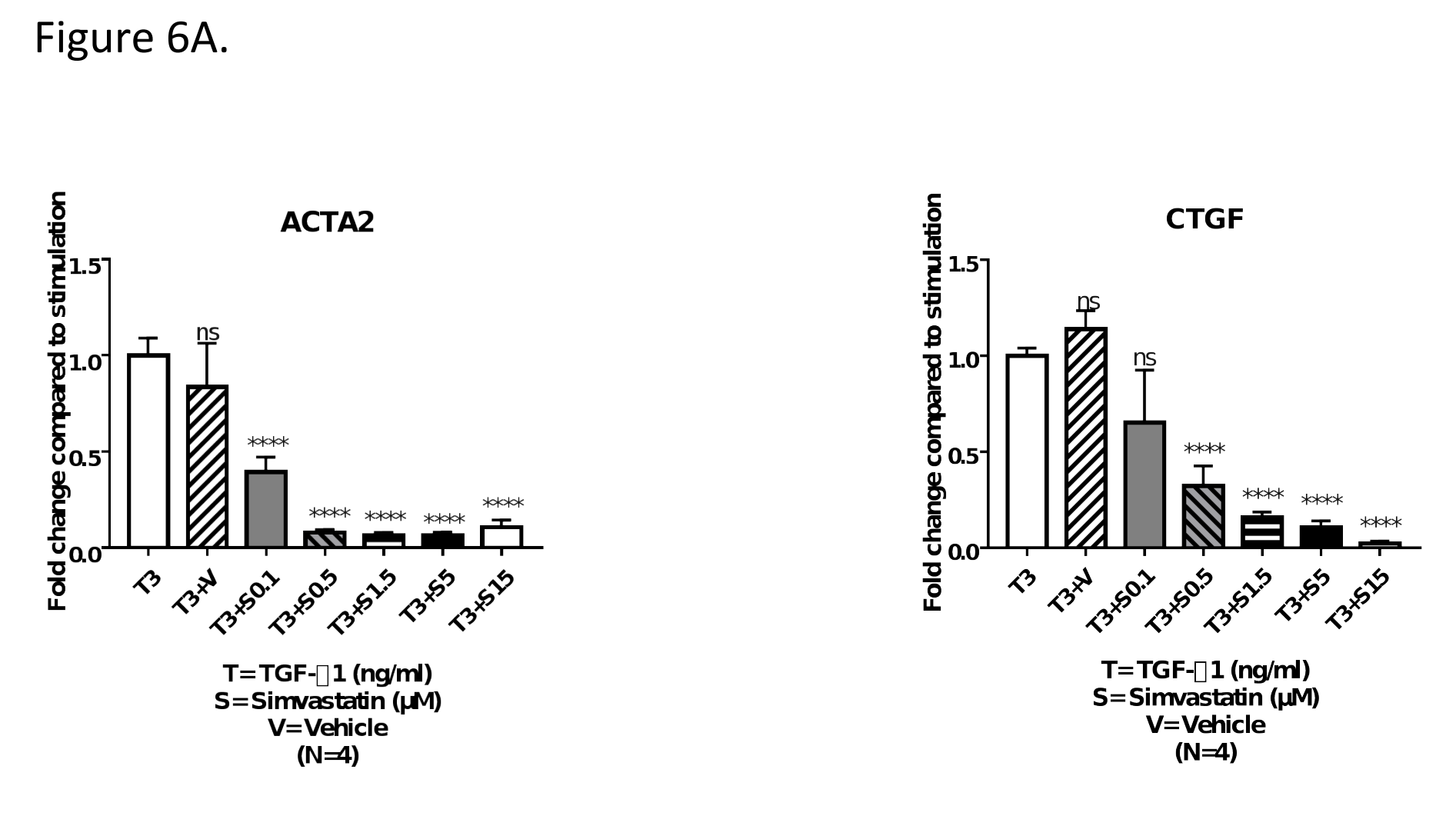





\section{Figure 6B.}

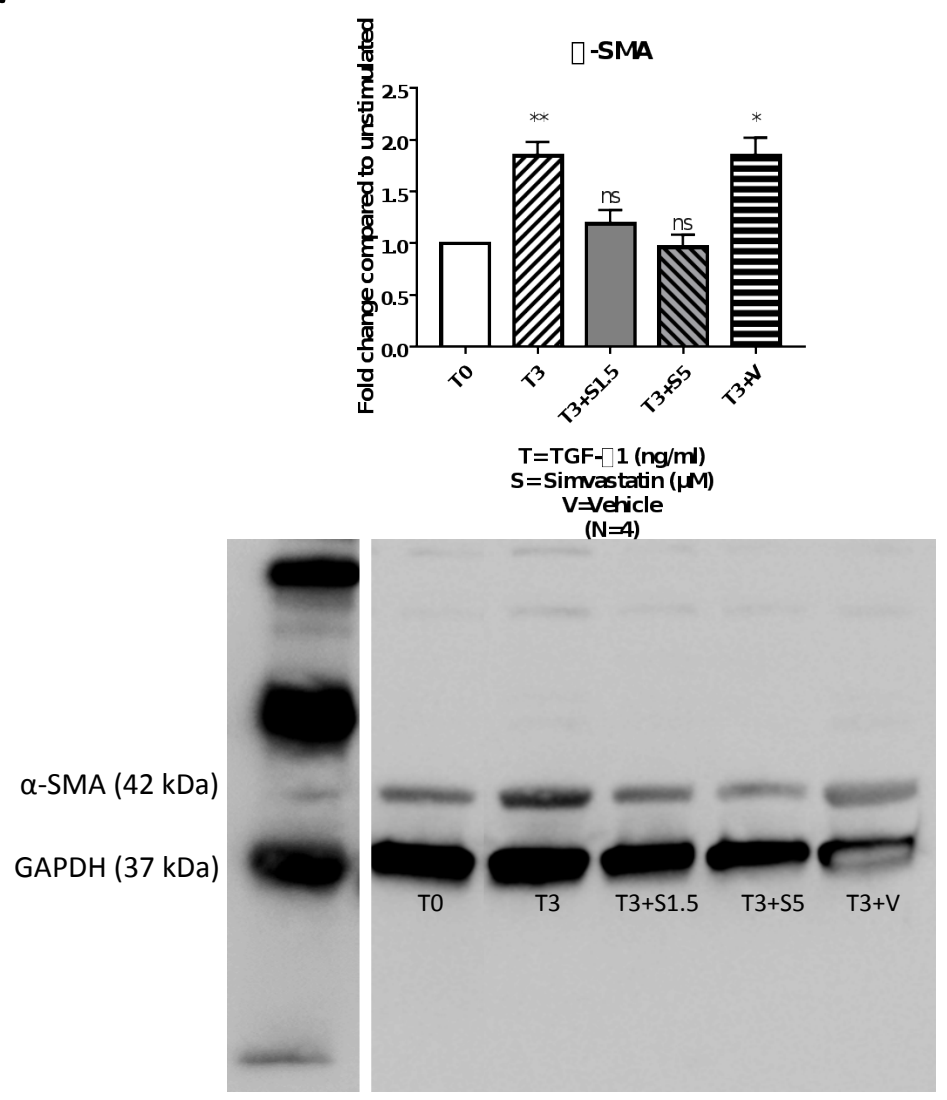


Figure 6C.

8
9
1
1
1
1
1
1
1
1
1
1
2
21
22
23
24
25
26
27
28
25
30
31
32
33
34
35
36
37
38
35
40
41
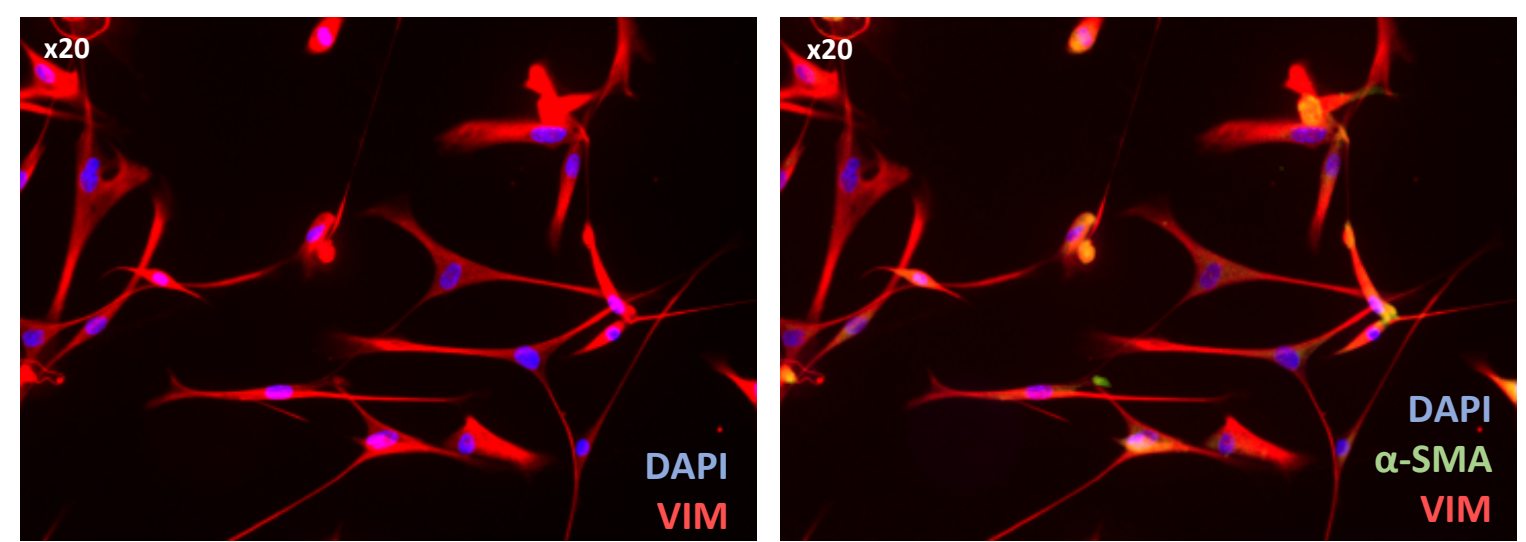

22
23

24

27

30

31

32

34

35

36

37

40

41 
Figure 6D.

TGF- $\beta 1$

$\times 20$

DAPI
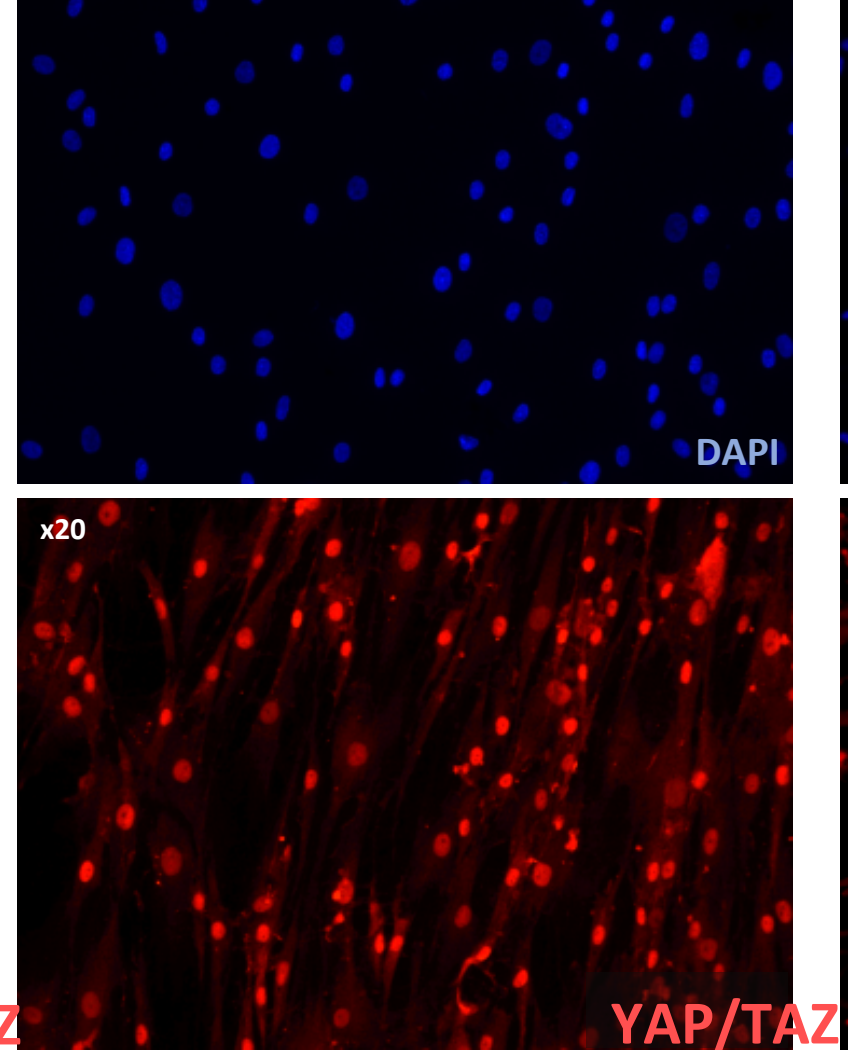

TGF- $\beta 1+$ Simvastatin

$\times 20$

DAP

$\times 20$

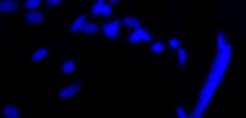

DAP

YAP/TA

38

39

40 